\title{
Critical Reflections Concerning the Concept of Participation in Social Intervention and
} Research

\author{
Helena Neves de Almeida
}

Professor and Researcher, Faculty of Psychology and Sciences of Education, University of Coimbra

Ana Maria Costa e Silva

Professor and Researcher, Institute of Education and Center for Studies in Communication and Society (CECS), University of Minho

\section{Abstract}

In processes oriented towards social change and transformation, the specification of different concepts and levels of participation is an important intellectual and epistemic challenge. Critical questioning of participation in social intervention and research is fundamental for structuring a common understanding and a grammar for intervention, which supports, in theory, the construction of a type of architecture of participation, that is, a conceptual network that sets the parameters for the evaluation of participation. The concept of participation, used so frequently in a populist way, can adapt as easily to objectives of regulation, as to social transformation, and can be subordinate to such divergent paradigms of social intervention such as task-centered interventions, the building of opportunities for development and the processes which aim to improve personal and social decision-making. One of the major goals of participation is to increase the power of individuals and collective decision-making. Beyond this individual and micro-level dimension, it reveals processes of co-construction of social alternatives and structures of opportunity on the meso level (the community) and the macro level (the political instance). Thus, participation in the present day constitutes a strategic axis for social intervention and research. It is necessary to reflect about it. How to operationalize participation? How important is the way it tackles and develops participation in research and transformative social intervention?

Keywords: participation, research, social intervention, social transformation

\section{Introduction}

The changes and transformations, which have taken place in economic, political and social affairs in recent decades have provided evidence of the necessary (re)configuration of society and the theme of participation assumes a strategic position for understanding the social process and answers needed to build or to activate.

As Dalrymple and Bolylan say "Participation is an active and dynamic concept, which draws attention to the social processes that social workers need to understand and respond to - such as upholding service users' and carers' rights, promoting the involvement/inclusion and challenging exclusion and marginalization" (2013, pp.90-91).

In processes focused on change and social transformation the specification of various concepts and levels of participation constitutes an important intellectual and epistemic challenge. It is fundamental that a common understanding be structured; namely, a type of grammar for intervention, which supports, in theory, the construction of a type of architecture of participation (Almeida \& Serra, 2016), that is, a conceptual network that sets the parameters for it evaluation.

In this process, the first issue to be raised is that of understanding the terminology used. We can use the same language but do the concepts have the same meaning for all of us? Are they being used as synonyms? What differentiates them?

The present article produces a theoretical exploration of different levels of conceptual understanding and offers for debate some arguments that demonstrate its polysemy by opening a place for the analysis of different meanings for participation in action and social research. 


\section{Conceptual polysemy: systematising diverse aproaches to participation}

The revision of literature allows us to identify different understandings of participation, such as: a process integrated in daily life (Hart, 1992), an unfinished process and an achievement (Demo, 1993), a conscious and informed action for the affirmation of individual and collective identity (Vieira, 2015). However, as Gohn refers (2003), participation is subject to interpretations, meanings and differentiated strategies according to the adopted analytical paradigms.

To facilitate the comprehension of the complexity of such analysis, we underline four approaches in the process of the concept consolidation of participation: The liberal and democratic conception, participation as a political act, the approach of objective-centered participation and participation as a strategic paradigm in public management and in social intervention.

\subsection{The liberal and democratic conception of participation}

Although it implies polycentric definitions, it is important to understand participation in its diverse dimensions, that is, the liberal conception and the democratic conception. According to the liberal conception, the concept can be understood along two distinct lines:

- corporative participation, which has the common good as the core of individuals, which presupposes that the motivation to participate is an external force beyond the personal interest of someone;

- community participation, which is characterized as an institutionalized form in which organized groups must participate within the apparatus of state power, where the public and the private spheres overlap.

According to Gohn (2013), the objective of participation in the liberal paradigm is the strengthening of civil society, as a way to prevent interference from the State; namely, any control, tyranny or meddling in individual lives. Carlos (2007) considers that this is an instrumental conception of participation and a strategy for the reduction of costs, through the actions of civil associations considered more efficient than the State in terms of certain actions given their proximity to the target-groups of public policy.

The democratic conception of participation can be understood from two perspectives:

- The revolutionary, which is structured in collectives organized to oppose the relationships of domination in favor of the division of political power. The party system is a fundamental actor and upholds the replacement of representative democracy with another system, i.e. participatory democracy.

- The radical democracy, which aims to strengthen civil society for the building of paths which - from a discursive point of view - open toward a more egalitarian social reality. This conception is pluralistic It relies on multiple agents to organize social participation and it articulates with the expansion of citizenship and the collective construction of political processes. The participatory budget and the different forums of popular participation are examples presented by the author of this typology.

In the minds of the people the democratic paradigm occupies a place, as the regulating principle of democracy by envisaging participation, as a phenomenon, which is developed in terms of both civil society and in the field of formal political institutions. Through the electoral process, the supreme criteria for the organization of individuals is centralized in the representative system and, as such, it is subject to certain existing defects in the liberal conception (such as favoritism) and/or the intended form of participation (co-option).

\subsection{Participation as a political act}

Dallari (1994) discusses the theme of political participation beyond electoral participation (be it as a voter, a candidate or a card-carrying member of the party). To participate is to also appear at party meetings, conventions or outreach groups, to become a member of cultural, recreational, and religious associations or to even to join in protests or marches, amongst other actions (Teixeira, 2001). The author adds that like social participation, political participation is a necessity of human 
nature and can be achieved within a strictly individual or collective identity (through integration into any type of social group) and in either a casual or organized way (with a view toward awareness) - with the latter being more efficient.

In a complementary way, Gohn $(2003$, p. 25$)$ reflects that political participation is usually viewed, as a process related to the number and intensity of individuals involved in decision-making by directly articulating with the topic of democracy in its direct and indirect forms (representative). The same author points out that political participation in public policies arises from the idea of community participation, that is, it is restricted to the incorporation of individuals working in assistance programs in the communities organized by authorities or missionary groups. Popular participation, which is defined as the participation of individuals in the processes of devising strategies and decision-making, only became a trend in the 1980s (depending on the contexts) and it was associated with popular movements - acting together with other types of participation, such as that of religious communities, unions and neighborhood associations, among others.

In these terms, the notion of popular participation is associated with a more demanding character being a feature of how social movements act by focusing on the response to social needs and the carrying out of protests including a combative position in terms of the State (Teixeira, 2001). However, in this context popular participation is defined by the organization of the people (excluding the circles of dominant power) to increase social control over resources and over the apparatus of the State, as well as its democratization. In light of this participatory process the political scenario of a country undergoes or may undergo change (Gohn, 2003; Paoli \& Telles, 2000).

\subsection{The approach of objective-centered participation}

Demo (2001) points to the methodological sense/meaning of participation, as a means and as an end. Amongst the objective of participation, the author highlights: • To seek out self-promotion, that is, to centre on personal interests with the objective of succeeding; - To implement citizenship, as implied in the reduction of injustices, the creation of strategies to react and the struggle for change; • To promote the exercise of democracy; • To control power not only via institutional means such as laws and decrees but also via control of the base; $\bullet$ To control bureaucracy by demanding patterns of effectiveness and efficiency in the public sphere; - To negotiate conflicts and disagreements; - To create a democratic culture expressed by participatory and transparent processes.

Bordenave (1985) brings up some other interesting discussion points for the overall understanding of the term. The author refers to participation, as something inherent to the social nature of man, that is, as a human necessity, which finds expression in the collective, through an affective base (integration) and an instrumental base (effectiveness and efficiency of actions). Reflecting on the origin of speech the author reiterates the perspective of Ammann (1978) and signals that what is truly crucial in participation is not how much one takes part but rather how one takes part. Thus, distinguishing between the processes of micro participation (personal and immediate interests) and macro participation (intervention at the core of social, political, and economic structures). Macro participation corresponds to social participation, which in the words of the author is inherent to the process, through which diverse social levels take part in the production, the management and the use of the goods of a historically determined society (Bordenave, 1985, p. 25). In this way, the author is highlighting the fallacy of political participation without a corresponding equity-based social participation.

\subsection{Participation as a strategic paradigm in public management and in social intervention}

In the 1990s, a new paradigm for public management appeared.

"Participation and related themes of choice, control, empowerment, personalization, partnership, and co-production have become central concepts in modern social policy" (Dickens, 2016, p. 107).

Popular participation and community participation have yielded their places to two new designations - social participation and citizen participation, respectively (Teixeira, 2001). For the author citizen participation originates in a complex and contradictory relationship involving civil society, the State and the market being one in which their roles are redefined via a civil society strengthened by the assumption of specific political duties and responsibilities, on the one hand, and the creation and exercise of rights with impact, as well on the social control of the State and the market, on the other. Citizen participation considers two contradictory elements: on the one hand, it expresses how the actors are "taking part" in the socio-political process, thus favoring their interests, identities and personal values and, on the other hand, in the civic sense it emphasizes the dimensions of universality, generality, the equality of rights, responsibilities and duties. (Teixeira, 2001, p. 32). 
As Nogueira (2005, p. 142) also adds, citizen participation has several focus points for action, which extend from the State to the market and to civil society, from the specific to the general and from ethics to individual interest. Practices, which involve citizen participation, strive to bring the decision-making sphere back to the local level, as they were conceived, as a form of periodic and planned social intervention, which encompasses the entire process of formulation and implementation of public policies. Institutionalization takes place, when beginning with structures created in the public system, which consist of representatives elected directly by society from which they come (Gohn, 2003). This author goes on to state that the actors involved in this process add a new dimension to the empowerment of groups and individuals via political and organizational skills training. As for the conception of social participation, it constitutes the target for the redefinition of social mobilization and the redefinition of the character of militancy in the diverse forms of participation that exist. The gathering of people for the sake of protests and demonstrations has become to be understood as energy to be channeled to reach common goals.

According to Gohn (2003, p. 59) the political content has been totally and completely drained from mobilization and its transfiguration into a process to achieve results. For Dagnino (2004) this new conceptual approach stems from the devaluation of social movements and from the accelerated growth of non-governmental organizations with an emphasis on the emergence of the Tertiary Sector, which has taken on a new role in the context of social reality. As the author remarks, the social participation envisioned for contemporary politics implies a change in trends for three notions that are quite dear to the process of democratic construction - civil society, participation, and citizenship - as a consequence of the politicalcultural dispute between two distinct projects. The first is the process of expanding democracy, as expressed in the creation of public spaces and in greater participation in civil society in terms of discussing and decision-making for public management, and second is the implementation of neo-liberal adjustment, which progressively relieves the State of its role of guaranteeing rights by transferring its social responsibilities over to civil society. The term civil society is increasingly being narrowed down to apply only to non-governmental organizations, if not just a mere synonym for the Tertiary Sector. Such a condition generates an erroneous conception of representation/representativeness, as one reduced to social visibility (the space occupied in various types of media). The neo-liberal redefinitions of citizenship diminish its collective meaning to a strictly individualistic understanding in addition to establishing a seductive connection between citizenship and the market. In other words, becoming a citizen has now come to signify the individual integration of a person into the market, as a consumer and producer.

This meaning of citizenship depoliticizes the dimension of universal rights and the political debate on the causes of poverty and inequality. With this in mind, citizenship is identified (and diminished) with solidarity and the moral responsibility of society, which is then called upon to connect with volunteer and philanthropic work. In turn, participation linked to these processes is redefined as:

- Solidarity participation with an emphasis on volunteer work and social responsibility for both individuals and businesses. Participation, therefore, is divested of its political and collective character by making civil society responsible for the resolution of social problems, which contrasts with the decidedly political and emancipating content of participation marked by the effective sharing of power between the State and society by means of deliberation inside new public spaces.

\section{Graduated scales and levels of participation}

Participation is a new strategic axis in current social intervention - a "quasi fashion", which is present in all approaches and models of social intervention in contemporary societies. Also in the field of social research; namely, in action-research the conceptions of participation and collaboration are frequently associated (Carr \& Kemmis, 1988; Silva \& Carvalho, 2016; Edwards-Groves, Olin \& Kalrberg-Granlund, 2016).

Thus, in the operational domain of the participative methodologies there emerge different but linked concepts such as collaboration, cooperation, agreement and partnership. All of them are based on logics of participation adapted to both regulatory objectives and social transformation that are subordinate to divergent paradigms of social intervention.

Participation takes on various meanings, senses, and connotations on an ascending graduated scale from manipulation to self-management depending upon its insertion into the procedures and practices of social and economic actors (Teodósio, 2004). This may imply advances, setbacks or biases contingent upon the political, ideological, social, economic and cultural angle of the analysis. 
Although participation constitutes a decisive factor in the democratization of relationships between the State and society, the guarantee of a more consistent action by the multiple social actors, nevertheless, remains an ambiguous and contradictory process. Participation possesses a discursive and pragmatic dimension within the scope of different intervening factors in different contexts, thus demonstrating socio-political conceptions that imply differentiated senses.

Civic, political and social rights (Carlos, 2007) are not gifts; they are rights. Note that the rights of the citizen are the rights to participate in the government of the city (Marshall, 1950). Thus citizenship acquires a status affiliated with the condition of full membership in a community and whoever possesses it enjoys equality with respect to the associated rights and duties (civil, political and social rights). It is for this reason that one speaks of citizen rights.

Reiterating the contributions of Dalrymple and Boylan (2013, p. 91) and citing Kirby et al. (2003, p. 5), "we used the term participation not only to mean "to take part" or "to be present at" but also to influence decisions and action. We also use the terms "involve" (passive verb) and participate (active verb) as synonyms."

With the expansion of political democracy and the progressive emergence of economic, social and cultural rights, "the image of the citizen changed and social citizenship was added on to political citizenship" (Madiot, 1995, p.14). The term social citizenship offers the possibility of being active in the production of norms of society and the potential to occupy a "durable social position" (Soulet, 1995, p. 129), which is free from any itinerary of insertion promoted by instances external to the subject. Although social citizenship does not have clearly established legal grounds, it goes beyond political citizenship and encompasses it. Solidarity and the guarantee of protection for those excluded are the pillars of its articulation.

As Ferreira and Almeida point out "the use of methodologies of participation plays an important role in the process of diagnosis, planning, action and evaluation of public policy and social intervention. Therefore, participation is not a passive variable; it interferes with the results in a positive or negative way, in a visible or invisible way. Integrating citizens' participation into the political process is a requisite, which decision-makers and professions cannot neglect" $(2016$, p. 8). On the organizational and social policy level participation is integrated in differentiated processes such as collaboration, consultation, partnership, cooperation, sharing, coordination, negotiation, networking and mediation. Here we are faced simultaneously with polarizing and differentiating definitions in terms of the sense and meaning assigned. Following a chronological order we can identify different graduated scales of participation that are presented in the article "The architecture of participation in transformative Social intervention processes" (Almeida \& Serra, 2016, pp. 120-121).

We reiterate here some of the more recent scales proposed by Jules Pretty (1995), Probst, Hagmann, Becker and Fernandez (2000) and Sherry Arnstein (2002).

Jules Pretty (1995) proposes a typology of participation that has been worked on in more recent works (Pretty \& Hine, 1999; Probst, Hagmann, Becker \& Fernandez, 2000; Cornwall, 2008) and that, while decreasing that scale or levels of participation, upholds evidence of a gradual and a conceptual differentiation scale, which is sistematized in Table 1.

Table 1 - Participation according to the typology of Pretty (1995)

\begin{tabular}{|l|l|}
\hline Manipulative participation & $\begin{array}{l}\text { Participation is only a pretension with representatives "of the people" on official boards but who } \\
\text { are not elected and have no power. }\end{array}$ \\
\hline Passive participation & $\begin{array}{l}\text { People are informed about what is going to happen or has happened. It is a unilateral } \\
\text { announcement by the administration or management of the project without any hearing of the } \\
\text { responses of the people. }\end{array}$ \\
\hline Participation for information sharing & $\begin{array}{l}\text { The shared information belongs only to external professionals. People participate by answering } \\
\text { questions posed by external researchers using surveys or similar approaches. People do not } \\
\text { have the opportunity to influence processes nor are the search results shared nor verified, as to } \\
\text { their accuracy. }\end{array}$ \\
\hline Participation by query & $\begin{array}{l}\text { The people participate by being questioned and the external agents hear opinions. These } \\
\text { external agents define the problems and solutions and can modify them in the light of the } \\
\text { responses of the people. Such a consultative process does not grant any participation in } \\
\text { decision-making and the professionals are not obliged to take on the views of the people. }\end{array}$ \\
\hline Participation by material benefits & $\begin{array}{l}\text { People participate by providing features such as work in exchange for food, money or other } \\
\text { incentives. Much of agricultural research falls into this category, as the farmers provide the } \\
\text { fields but are not involved in experimenting or in the learning process. It is very common to see }\end{array}$ \\
\hline
\end{tabular}




\begin{tabular}{|l|l|}
\hline & $\begin{array}{l}\text { this type of participation, where people have no interest in prolonging the activities, when the } \\
\text { incentives end. }\end{array}$ \\
\hline Functional participation & $\begin{array}{l}\text { People participate in forming groups to meet predetermined objectives related to the project, } \\
\text { which may involve the development or promotion of a social organization initiated externally. } \\
\text { This participation does not tend to be in the early stages of project planning or cycles but after } \\
\text { the major decisions have already been taken. These institutions tend to be dependent on } \\
\text { external facilitators and initiators but they can become self-sufficient. }\end{array}$ \\
\hline Interactive Participation & $\begin{array}{l}\text { People participate in joint analyses, which leads to action plans and the formation of new local } \\
\text { institutions or the strengthening of existing ones. It tends to involve interdisciplinary } \\
\text { methodologies seeking multiple goals and makes use of systematic and structured learning } \\
\text { processes. These groups take on the ownership control of local decisions, so people have a } \\
\text { stake in maintaining the structures or practices. }\end{array}$ \\
\hline Self-mobilization & $\begin{array}{l}\text { People participate in taking initiatives to change systems independently of external institutions. } \\
\text { This self-initiated mobilization and collective action may or may not challenge the existing } \\
\text { unequal distribution of wealth and power. }\end{array}$ \\
\hline
\end{tabular}

Source: Synthesis drawn from the work of Pretty, J. (1995) Participatory learning for sustainable agriculture, World Development, 23 (8), 1252

Probst, Hagmann, Becker and Fernandez (2000) established a typology that describes only four modes by establishing a scale that progresses all the power that lies with a single actor to a distribution of power over all the participating parts concerned:

- Contractual Participation: A social actor has decision-making power on most of the decisions taken in innovation processes and can be considered the "owner" of the process. Others participate in activities defined by this group of interested parties, that is, those who are (formally or informally) "hired" to provide services and support.

- Advisory Participation: Most of the key-decisions are held within a group of interested parties but the emphasis is placed on consultation and gathering information with others, especially for the identification of constraints and opportunities, priority setting and/or assessment.

- Collaborative Participation: Different actors collaborate and are placed on equal footing, thus, emphasizing the connection through an exchange of knowledge, different contributions and a sharing of the power of the innovation process.

- Partnership Participation: Different actors work together, as colleagues or partners. "Ownership" and responsibility are distributed equally between the partners and decisions are made by agreement or consensus among all stakeholders.

Sherry Arnstein (2002) - author of the article A Ladder of Citizen Participation published in 1969 in the Journal of the American Planning Association - is a reference in the scientific community about the construction of evaluative scales of participation. This author defines a range of participation consisting of eight levels, which correspond to the magnitude of power and decision-making. At the lowest level is the degree of manipulation and therapy (almost non-participation) and this is followed by other levels, where there is a minimal distribution of power (respectively, information, consultation and peace-making) and, finally, the last three levels, which represent the level of power associated with the status of citizenship (partnership, delegation of power and, finally, control by the citizen). Racism, paternalism and resistance to sharing power constitute obstacles that were not considered in the structuring of the scale.

The identified scales present diverse levels of participation. However, although using similar or equal designations, they do not always correspond among the various authors. Nevertheless, they introduce an analytical architecture with interesting contributions for an understanding of the conceptual, ideological and, necessarily, ethical complexity that underlies the use of the term "participation" in the participatory methodologies of action and social research.

It is important to point out that the analysis of participation, as analytical paradigms and typologies, contributes to its conceptualization, although all classifications present limitations, since models do not exist as unique doctrines. They have always contextual limitations in time and space and the economic, social and political dimensions influence one another. As Carlos (2007) warns such typologies are combined and coexist in different ways - more or less intensely - depending on the situation and the actors involved. 


\section{Critical reading about the potentials and limits of participative methodologies}

The specialized literature in the field of participative methodologies in action and social research refers to participation, as a fundamental dimension of social action. Indeed, there are various perspectives - political, cultural, scientific, social - that assume participation, as a leitmotiv associated with civic participation, cultural and scientific produçtion, social implication and regulation, citizenship, emancipation and transformation.

Furthermore, there are a diversity of methodologies and techniques for the promotion of the participation of people, groups and communities in the production of information, social diagnosis and in the co-construction of knowledge. The participative methodologies find themselves associated with the all-inclusive and socio-critical paradigm of the construction of knowledge, valuing meanings and representations attributed by people in their daily life. From among the diversity of procedures and techniques used one can highlight: brainstormimg, design thinking, photovoice, Delphi Inquiry, focus group, communities of practice, storyboard, World Cafe (cf. Ferreira \& Almeida, 2016).

Each one of these methodologies has inherent objectives, scopes and various limitations with respect to its implementation and complexity in the promotion of participation. Also the articulation between knowledge of proximity and analytical distancing are aspects to take into account during controversial times particularly at the level of research and in debates about the influence of interaction in the production of evidence.

The theoretical revision and completed analysis permit configuration of a puzzle of multiple senses about the meanings of and approaches to participation. The conceptual and paradigmatic typology recuperated tries out an architecture of participation, whose objective is to organize a common understanding about levels of participation, which are necessarily associated with polítical, cultural, social, economic dimensions, amongst others.

This systematization allows for the analysis of diverse nuances of participation and consideration of ethical models and levels of recognition (Edwards-Groves, Olin \& Kalrberg-Granlund, 2016) associated with the participants in the social action and research: demanded, fake, permitted, desired, citizen participation.

Also standing out is the importance of being aware of the potentials and limits of participation integrated in diverse contexts (individual, social, cultural, polítical, etc) not forgetting the ethical questions at times subsumed in a praxis of control, regulation or self-determination. Thus, the conceptual architeture modelled here draws attention to the conceptual desconstruction-configuration and ethical challenges, which are at times made invisible in the conceptual polissemy of the participation and in the methodologies designated as participatory.

Finally, it is mportant, to underline the potentials of participatory methodologies in the development of the processes of construction of change and social transformation at the micro, meso and macro social levels, as well as in the construction and democratization of knowledge, particularly when making sure of the interative participation, mobilizing of recognition and the self-determination of the various interveners.

\section{References}

[1] Almeida, Helena and Vaz Serra, Pedro (2016). The architecture of participation in transformative Social intervention processes. The 4 th International Virtual Conference on Advanced Scientific Results (SCIECONF2016), June 6 - 10, 2016 (www.scieconf.com, Slovakia), pp. 119-122. elSSN: 1339-9071, cdISSN: 1339-3561. ISBN: 978-80-554-1234-4.

[2] Ammann, S. (1978). Participação Social (2nd. ed.). São Paulo: Cortez \& Moraes.

[3] Arnstein, S. (2002). Uma Escala da Participação Cidadã. Participe, Revista da Associação Brasileira para Promoção da Participação: 4-13. https://pt.scribd.com/doc/80153647/Arnstein-Uma-Escada-Da-ParticipacaoCidada (consulted in January 2016)

[4] Bordenave, J. (1985). O que é comunicação rural (2nd. ed.). São Paulo: Brasiliense.

[5] Bourque, D. (2008). Concertation et partenariat: entre levier et piège du développement des communautés. University of Quebec Press. ISBN: 978-2-7605-1582-6

[6] Carr, W. and Kemmis, S. (1988). Teoria crítica de la enseñanza: la investigación - acción en la formación del professorado. Barcelona: Ediciones Martinez Roca.

[7] Carlos, E. (2007). Controlo Social e Justiça Redistributiva no Orçamento Participativo (1st. ed.). Vitória/ES: Edufes: $31-68$ 
[8] Cornwall, A. (2008). Unpacking 'Participation': models, meanings and practices. Oxford University Press and Community Development Journal.

[9] Dagnino, E. (2004). Construção Democrática, Neoliberalismo e Participação: os Dilemas da Confluência Perversa. Política \& Sociedade, Revista de Sociologia Política, Florianópolis (1): 137-161.

[10] Dallari, D. (1994). O Que É Participação Política? São Paulo: Brasiliense.

[11] Dalrymple, J. and Boylan, J. (2013). Effective Advocacy in Social Work. London: Sage Publications.

[12] Demo, P. (2001). Participação é Conquista: Noções de Política Social. São Paulo: Cortez.

[13] Dickens, J. (2016). Social work and social policy. An introduction. 2nd ed., New York: Routledge.

[14] Edwards-Groves, C.; Olin, A. and Kalrberg-Granlund, G. (2016). Partnership and recognition in action research: understanding the practices and practices architectures for participation and change, Educational Action Research, V. 24, N.3, 321-333,

[15] Ferreira, V. and Almeida, H. (2016). Kit de ferramentas para diagnósticos participativos. Projeto Internacional Local Gender Equality - Mainstreaming de Género nas Comunidades Locais. Coimbra: CES - Centro de Estudos Sociais. ISBN: 978-989-8847-02-7. Printed edition: ISBN: 978-989-8847-01-0.

[16] Gohn, M. (2003). Conselhos Gestores e Participação Sociopolítica. São Paulo: Cortez.

[17] Hart, R. (1992). Children's Participation: From Tokenism to Citizenship. UNICEF. www.unicefirc.org/publications/100 (consulted in March 2016)

[18] Kirby; P.; Lanyon, C.; Cronin, K. and Sinclair, R. (2003). Building a Culture of Participation: Research Report. London: Department for Education and Skills.

[19] Madiot, Y. (1995). Citoyenneté, un concept a facettes multiples. In G. Koubi, De la citoyenneté. Paris: Litec. 1995.

[20] Marshall, T.H. (1950). Citizenship and Social Class. Cambridge University Press.

[21] Nogueira, M. (2005). Um Estado Para a Sociedade Civil: Temas Éticos e Políticos da Gestão Democrática (2nd. ed.). São Paulo: Cortez.

[22] ONU (1966). Pacto dos Direitos Económicos, Sociais e Culturais.

[23] Paoli, M. and Telles, V. S. (2000). Direitos Sociais: Conflitos e Negociações no Brasil Contemporâneo. In S. Alvares., E. Dagnino and A. Escobar (Eds.) Cultura e Politica nos Movimentos Sociais Latino-Americanos. (pp. 103-148). Belo Horizonte: Editoria.

[24] Pateman, C. (1992). Participação e Teoria Democrática. Rio de Janeiro: Paz e Terra.

[25] Pretty, J. (1995). Participatory learning for sustainable agriculture. World Development, 23 (8), 1247- 1263

[26] Probst, K., Hagmann, J., Becker, T. and Fernandez, M. (2000). Developing a framework for participatory research approaches in risk prone diverse environments. Deutscher Tropentag 2000 in Hohenheim

[27] Silva, A. M. C \& Carvalho, M. L. (2016). A investigação-ação ao serviço da pedagogia crítica e democrática. Estreiadiálogos (Revista da Rede Internacional de Investigação-Ação Colaborativa), 2, 9-17. Accessible online: https://www.estreiadialogos.com/n2

[28] Soulet, M-H. (1995). Politique de la pitié, politique de l'urgence, politique du risque: quelques fondements à l'intervention sociale dans une perspective des droits de l'homme. In EASSW, Human Rights \& Social Work Education. Final Report of the EASSW European Seminar.

[29] Teixeira, E. (2001). O local e o Global: Limites e Desafios da Participação Cidadã. São Paulo: Cortez.

[30] Teodósio, A. (2004). Democracia Electrónica e Terceiro Sector: Novos Formatos, Velhos Dilemas da Participação Popular. São Paulo: Integração: 1-15.

[31] Vieira, I. (2015). A Participação. Um paradigma para a intervenção social. Lisboa: Universidade Católica Editora. 